\title{
Do Stem Cells Exist in the Adult Kidney?
}

\author{
Sandeep Gupta Mark E. Rosenberg \\ Department of Medicine and Stem Cell Institute, University of Minnesota, Minneapolis, Minn., USA
}

\section{Key Words}

Acute renal failure $\cdot$ Oct- 4 stem cell marker $\cdot$ Progenitor cells · Sca-1 stem cell marker - Stem cells, regeneration

\begin{abstract}
Adult stem cells exist in many organs and play a critical role in normal cell turnover and the response to injury. The existence of adult stem cells in the mammalian kidney remains controversial. Kidney stem cells have been isolated and characterized by many groups, often with discrepant results. This article will review the current state of knowledge regarding adult kidney stem cells and discuss future directions for kidney stem cell research.

Copyright $\odot 2008$ S. Karger AG, Basel
\end{abstract}

\section{Introduction}

Stem cells are specialized cells that have the capacity to renew themselves and differentiate into specialized cell types. Adult stem cells are found in differentiated tissues and can give rise to specialized cells of that tissue. A progenitor cell is generally considered a more intermediate cell between a stem cell and a differentiated cell. This partially specialized cell can divide and generate new progenitor cells, but is usually viewed as generating differentiated cells. Growing attention has focused on organ-specific adult stem cells both to better understand how injured organs regenerate and as a therapeutic target for disease modulation. Adult stem cells and their niches have been well characterized in such sites as the bone marrow, intestine, skin, and brain [1-3]. There is ongoing

\section{KARGER}

Fax +41613061234

E-Mail karger@karger.ch

www.karger.com
(C) 2008 S. Karger AG, Basel

0250-8095/08/0284-0607\$24.50/0

Accessible online at:

www.karger.com/ajn debate and controversy on whether stem cells exist in the adult kidney, and if they do, what role these cells play in the pathophysiology of kidney disease. Much of this interest in adult kidney stem cells has derived from studies of the regenerative response following acute kidney injury (AKI).

\section{Kidney Regeneration following AKI}

Toxic and ischemic insults to the kidney lead to AKI, most often manifest as acute tubular necrosis. Loss of injured or dead cells leads to denudation of tubular basement membrane, with sloughed cells and cellular debris filling tubular lumens. Following injury, the kidney undergoes a robust regenerative response, leading to recovery of kidney function. New cells are required to replace damaged cells. Three possible sources of new tubular cells are: adjacent less damaged tubular cells, extrarenal cells presumably of bone marrow origin that home to the injured kidney, or resident kidney stem cells.

There is evidence that bone marrow-derived cells can migrate to the kidney and form tubular epithelial cells following AKI [4-8]. However, the in vivo contribution of extrarenal cells to kidney regeneration is minimal [911]. Arguments for less damaged tubular cells as being the source of regenerating cells come from studies of gene expression following AKI [12]. Recapitulating developmental paradigms, these cells dedifferentiate, proliferate, and eventually reline denuded tubules restoring the structural and functional integrity of the kidney [12-17]. Molecular events defining this regenerative response have been characterized and strategies to accelerate the 
Table 1. A summary of studies isolating kidney stem cells

\begin{tabular}{|c|c|c|c|c|c|c|c|}
\hline Authors & Species & Isolation method & Stem cell markers & Other markers & Location & $\begin{array}{l}\text { Differentiate } \\
\text { into kidney } \\
\text { tubules }\end{array}$ & $\begin{array}{l}\text { Differentiate into } \\
\text { other lineages }\end{array}$ \\
\hline Oliver et al. [36] & rat & label retaining & & & papilla & yes & neuron \\
\hline Maeshima et al. [38] & rat & label retaining & & & proximal tubule & yes & not tested \\
\hline Iwatani et al. [39] & rat & side population & Sca-1 & C-kit, CD45 & proximal tubule & no & heme, muscle, liver \\
\hline Hishikawa et al. [40] & mouse & side population & Sca-1 & Musculin/MyoR & interstitium & not tested & not tested \\
\hline Challen et al. [41] & mouse & side population & Sca-1, CD24 & endoglin/CD105 & tubule & yes & osteocyte, adipocyte \\
\hline Bussolati et al. [42] & human & marker & CD133 & Pax-2, CD44 & interstitium & yes & endothelium \\
\hline Sagrinati et al. [43] & human & marker & $\begin{array}{l}\text { Oct-4, CD24, } \\
\text { CD133, Bml1 }\end{array}$ & & $\begin{array}{l}\text { glomerular parietal } \\
\text { epithelium }\end{array}$ & yes & $\begin{array}{l}\text { osteocyte, adipocyte, } \\
\text { neuron }\end{array}$ \\
\hline Dekel et al. [44] & mouse & marker & Sca-1 & & $\begin{array}{l}\text { interstitium of } \\
\text { papilla }\end{array}$ & not tested & $\begin{array}{l}\text { osteocyte, adipocyte, } \\
\text { neuron }\end{array}$ \\
\hline Kitamura et al. [45] & rat & culture & Sca-1, Musashi-1 & Pax-2, Wt-1, Wnt-4 & proximal tubule & yes & not tested \\
\hline Gupta et al. [46] & rat & culture & Oct-4, Rex-1 & Pax-2, CD44 & proximal tubule & yes & $\begin{array}{l}\text { neuron, liver } \\
\text { endothelium }\end{array}$ \\
\hline
\end{tabular}

repair process tested in both experimental models and in humans [12-19]. The rapidity and extent of DNA synthesis and cell proliferation that follow kidney injury have been used to support a role for remaining epithelial cells as the major source of regenerating cells. It has been argued that the response is too large to be accomplished by a small number of putative adult stem cells residing in the kidney. However, this argument does not take into account the potential presence of transit amplifying cells that may be present in the kidney. Transit amplifying cells are rapidly cycling, but can acquire differentiated function and eventually undergo terminal differentiation [20]. Moreover, the cell cycle dynamics of stem cells is far from being understood.

Other arguments favoring less damaged cells include cell lineage tracking studies demonstrating that differentiated tubular epithelial cells can proliferate and repopulate damaged tubules following AKI $[21,22]$. However, these studies do not rule out the possibility that kidney stem cells can express epithelial markers, nor do they exclude a role for kidney stem cells as contributing to the regenerative response.

Outcomes following an episode of AKI are poor, with an in-hospital mortality $>50 \%$ in individuals who develop postoperative AKI requiring dialysis [23]. Even after multivariate adjustment, AKI continues to remain an independent risk factor for mortality [24]. Animal models have demonstrated permanent damage to peritubular capillaries, interstitial fibrosis, and altered gene expression following an episode of AKI [25]. These observations suggest that AKI is not always a fully reversible condition and can lead to permanent changes in the kidney. This poor outcome may be due to an inadequate regenerative response, perhaps related to the availability of kidney stem cells. Also, consumption of kidney stem cells following AKI may explain why AKI often accelerates the progression of underlying chronic kidney disease. A potential role for stem cells in other kidney disease states is less well defined. Stem cell depletion could be a pathophysiological factor in many chronic progressive kidney diseases.

\section{Lessons from Development and Lower Organisms}

Stem cells exist in the metanephric mesenchyme, which is the tissue of origin for most of the structures of the mature kidney, except for the collecting duct, interstitium, and vasculature [26, 27]. Multipotent stem cells have been localized to the lower tubule and ureter of the Drosophila Malpighian tubules [28]. These cells are present in abundant numbers, undergo self-renewal, and can give rise to all cell types of the adult Malpighian tubule. In contrast to other stem cells that are regulated in fixed niches through specific signaling between them and adjacent supporting cells, these cells autoregulate their selfrenewal and differentiation behavior through the JAKSTAT signaling pathway. Kidney stem cells persist in the adult kidneys of other organisms, such as the skate and the freshwater teleost. These cells can participate in new nephron formation following partial nephrectomy [2931]. 
Knowledge derived from kidney development and lower organisms has contributed to the study of adult kidney stem cells. The molecular signature of developing kidney cells has been used to define stem cell markers in order to identify and track adult stem cells. For example, CD24 and cadherin-11 are two cell surface proteins that are strongly expressed by uninduced metanephric mesenchyme [32]. However, this approach has been difficult given the complex nature of kidney development, with the metanephric kidney being preceded by the pronephros and mesonephros, and the fact that mesenchymal-to-epithelial transformation must occur during development. Nonetheless, pathways involved in cell lineage progression in the metanephric kidney have provided important clues to manipulate embryonic and adult stem cells to undergo kidney cell lineage progression. Metanephric organ culture has been used as a readout to define the differentiation potential of injected stem cells. Finally, both the metanephric mesenchyme and the intact metanephric kidneys are being used in experimental studies for the treatment of adult kidney diseases [33, 34].

\section{Isolation of Adult Kidney Stem Cells}

The lack of a definitive marker for kidney stem cells makes it difficult to isolate adult kidney stem cells, to define a kidney stem cell niche, or to follow cell lineage progression in the normal or injured kidney. The kidney is a particularly challenging organ to work with, given its complex architecture comprised of at least 26 different cell types. Candidate adult kidney stem cells have been isolated using four different selection strategies that have been used to successfully isolate stem cells from other organs. The first method takes advantage of the fact that stem cells are slow-cycling cells. Therefore, when the DNA of the cells is labeled with a marker such as bromodeoxyuridine, the cells retain the label for a long period of time. This label retention can be used to identify and isolate putative stem cells. The second method of isolating side-population (SP) cells takes advantage of the fact that SP cells extrude Hoechst dye through the activity of multidrug resistance proteins that are part of the ATP-binding cassette transporter superfamily. SP cells (Hoechst low cells) isolated from many different organs contain multipotent stem cells [35]. The third method used to identify and isolate kidney stem cells takes advantage of specific cell surface markers that have been used to identify stem cells in other organs or the metanephric kidney. The markers used to isolate kidney stem cells in- clude CD133, stem cell antigen-1 (Sca-1), and CD24. The fourth method has been to use culture conditions that have been successful in selecting stem cells in other organ systems.

\section{Label-Retaining Cells}

Oliver et al. [36] have isolated cells from the kidney papilla of young mice and rats that are slow-cycling cells and have characteristics of kidney stem cells. When grown in culture, these papillary cells express epithelial and mesenchymal markers, form cellular spheres, and display some evidence of plasticity with differentiation into neurons under appropriate culture conditions. These cells proliferate and migrate following in vivo ischemic kidney injury.

Maeshima et al. [37] identified a population of cells in the adult rat kidney scattered among kidney tubular cells. These cells were identified as label-retaining cells and were found predominantly in proximal tubules. Following kidney ischemia, these label-retaining cells undergo proliferation, and progeny of these cells initially express vimentin, a mesenchymal cell marker, and later become positive for E-cadherin, an epithelial cell marker. The cells that have been subsequently isolated demonstrate plasticity and can be integrated into the developing kidney [38].

\section{SP Cells}

Three different groups isolated and characterized kidney SP cells. Iwatani et al. [39] isolated SP cells from adult rat kidney that comprised $0.03-0.1 \%$ of the cells of the digested kidney. These cells do not participate in kidney regeneration following experimental glomerulonephritis or tubular injury induced by gentamicin. Hishikawa et al. [40] isolated SP cells from adult mouse kidneys that express Musculin/MyoR, a transcription factor found in skeletal muscle precursors. These cells localize to the kidney interstitium. The number of cells decreases following AKI, and infusion of the cells is associated with the expression of kidney-protective factors and improved kidney function in an acute model of kidney injury, but not in chronic kidney disease. Challen et al. [41] isolated SP cells from adult mouse kidney, where they comprise $0.14 \%$ of the kidney cells. These cells do not express Musculin/MyoR, have multilineage differentiation potential, and are heterogeneous, including the presence of a monocytic component. Interestingly, these cells express genes involved in Notch signaling. Kidney-protective, paracrine effects are observed following infusion of these cells in AKI. 
Candidate Markers Used to Isolate Kidney Stem Cells

Bussolati et al. [42] isolated and cultured a population of cells from adult human kidneys using CD133 as a selection marker. These cells can be differentiated in vitro and in vivo into epithelial and endothelial cells, can form tubules and vessels, and express early and late nephron markers. Injection of these cells 3 days following myoglobinuric AKI resulted in some incorporation of these human cells into mouse tubules. These cells have limited self-renewal properties and express HLA class I antigens.

Sagrinati et al. [43] used CD24 and CD133 to select a subset of parietal glomerular epithelial cells that have a high self-renewal potential and can be differentiated into kidney tubular cells, as well as osteocytes and adipocytes. Injection of these cells into SCID mice with myoglobinuric AKI resulted in incorporation of injected cells into regenerating tubules and improved kidney function.

Dekel et al. [44] used Sca-1 magnetic cell sorting to isolate nontubular Sca-1-positive cells from mouse kidneys. The cells are present in the interstitium of the kidney and can differentiate into myogenic, osteogenic, adipogenic, and neural lineages. When injected into the kidney parenchyma in a model of AKI, the cells adopt a kidney phenotype.

\section{Selective Culture Conditions}

Kitamura et al. [45] isolated a population of rapidly proliferating cells from microdissected proximal tubules that express the stem cell markers Sca-1 and Musahi- 1 as well as early nephron markers. These cells can differentiate into mature tubular cells in culture. These cells have a triploid karyotype, although they do not undergo tumor formation in nude mice.

Gupta et al. [46] isolated a unique population of cells from rat kidneys that were called multipotent renal progenitor cells. Features of these cells include: spindleshaped morphology, self-renewal for over 200 population doublings without evidence for senescence, normal karyotype and DNA, expression of vimentin, CD90 (Thy1.1), Pax-2, and Oct-4, but not cytokeratin, MHC class I or II, or other markers of more differentiated cells. Multipotent renal progenitor cells exhibit plasticity demonstrated by the ability of the cells to be induced to express endothelial, hepatocyte, and neural markers by quantitative RT-PCR and immunohistochemistry. The cells can differentiate into kidney tubules when injected under the capsule of an uninjured kidney or intra-arterially following kidney ischemia-reperfusion injury.

\section{Summary}

A summary of studies isolating kidney stem cells is given in table 1. Differences in the cells isolated in these studies may be due to different selection markers, species of origin, age of the kidneys, and culture conditions. The different cells have been localized to multiple sites in the kidney, including tubular and interstitial cells of the kidney papilla, the proximal tubule, the cortical interstitium, and the parietal epithelial cells of the glomerulus. Different markers have been used to confirm these localizations, although in many cases it remains a challenge to confirm whether the cells isolated are the same as the in vivo cells. Despite this, the proximal tubule was a site for the stem cells in many of the studies. Interestingly, the proximal tubule is the site of greatest injury in AKI. Hence, it is logical to house stem cells at the site of maximal demand.

The isolated cells express a number of stem cell markers including Sca-1, Oct-4, Rex-1, and CD24 and CD133. The marker expressed by many of the cells was Sca-1. Sca1 is a member of the Ly- 6 family and is one of the earliest cell surface markers of hematopoietic stem cells, but has since been found to be expressed in bone marrow-derived multipotential cells and skeletal muscle satellite cells and is also present on mature cells. Oct- 4 (also referred to as POU5F1) is a POU (Pit-Oct-Unc)-domain transcription factor expressed in embryonic stem cells, as well as in primordial germ cells and adult gonads [47-50]. Oct-4 plays a critical role in maintaining pluripotency of embryonic stem cells and the viability of primordial germ cells [48, 50-52]. Differentiation of embryonic stem cells is associated with downregulation of Oct- $4[53,54]$. Oct4 expression has been demonstrated in stem cells isolated from umbilical cord blood, bone marrow, hair follicles, muscle, skin, breast, pancreas, liver, amniotic fluid, as well as endothelial progenitor cells and neural stem cells [47, 55-68]. These markers will be useful to localize a kidney stem cell niche and can be used to study cell lineage progression in the normal and injured kidney.

\section{Future Directions}

Despite significant advances in the field of kidney stem cells, significant major issues remain unresolved. The fundamental question of whether stem cells exist in the adult kidney remains controversial. Many groups have isolated cells from the kidney with properties of kidney progenitor cells, although the phenotype of many of these cells may be influenced by in vitro culture condi- 
tions. Defining kidney stem cell markers is critical for the field to move forward. Such markers will allow for the characterization of the kidney stem cell niche and the signaling pathways that control stem cell behavior in the normal and injured kidney. The presence of stem cells in the adult kidney has important implications for our understanding of normal cell turnover in the kidney and the source of regenerating cells following AKI. Identification of kidney stem cell markers will set the stage for transgenic strategies to define such kidney cell lineage progression.

The in vitro differentiation of kidney stem cells can provide an important model system to study the cell biology involved in nephron formation and to dissect the role of specific factors in kidney cell lineage progression. Understanding the process of mesenchymal-epithelial transformation may also lead to strategies to limit or reverse kidney interstitial fibrosis. During the process of fibrosis, epithelial cells undergo epithelial-mesenchymal transformation, leading to migration of cells from the tubule to the interstitial space and subsequent transformation into fibroblasts [69-72]. The potential to reverse this process through mesenchymal-epithelial transformation has exciting therapeutic potential for the treatment of chronic kidney disease. In vitro generation of kidney tubular epithelial cells from stem cells would also be critical for developing a supply of cells to be used for cellular therapy, or a source of cells for kidney tubular assist devices.

AKI is associated with a poor short-term prognosis and adverse long-term effects on kidney function. The lack of specific beneficial therapies has led investigators to explore strategies both to protect against kidney injury and to accelerate the repair process [73-77]. In most cases, strategies targeting kidney protection are dependent on knowing ahead of time when the injury event will occur. Therapeutic strategies directed at enhancing kidney repair have the potential to limit the duration of AKI and to better preserve long-term kidney function. Pharmacologic therapies directed at enhancing kidney regeneration are limited in their scope and have been unsuccessful when applied to the treatment of human AKI [78, 79]. On the other hand, cellular therapies using bone marrow- or kidney-derived stem cells can affect a number of different mechanisms, both autocrine and paracrine, and, therefore, have greater potential to enhance repair. In addition, stem cells could be used to deliver therapeutic genes or proteins to the injured and regenerating kidney.

Stem cell depletion may be a pathophysiological factor in many chronic progressive kidney diseases. The ability to identify and quantify stem cell numbers is essential to the study of this 'stem cell depletion hypothesis' and is dependent on the identification of stem cell markers. The availability of these tools along with a greater understanding of the in vivo control of stem cell behavior will enable studies to increase stem cell numbers and/or to accelerate the replacement of injured or dying cells through genetic and pharmacologic strategies.

\section{References}

-1 Tumbar T, Guasch G, Greco V, Blanpain C, Lowry WE, Rendl M, Fuchs E: Defining the epithelial stem cell niche in skin. Science 2004;303:359-363.

2 Moore KA, Lemischka IR: Stem cells and their niches. Science 2006;311:1880-1885.

$\checkmark 3$ Naveiras O, Daley GQ: Stem cells and their niche: a matter of fate. Cell Mol Life Sci 2006; 63:760-766.

4 Poulsom R, Forbes SJ, Hodivala-Dilke K, Ryan E, Wyles S, Navaratnarasah S, Jeffery R, Hunt T, Alison M, Cook T, Pusey C, Wright NA: Bone marrow contributes to renal parenchymal turnover and regeneration. J Pathol 2001;195:229-235.

5 Gupta S, Verfaille C, Chmielewski D, Kim Y, Rosenberg M: A role for extrarenal cells in the regeneration following acute renal failure. Kidney Int 2002;62:1285-1290.
6 Lin F, Cordes K, Li L, Hood L, Couser WG, Shankland SJ, Igarashi P: Hematopoietic cells contribute to the regeneration of renal tubules after ischemia-reperfusion injury in mice. J Am Soc Nephrol 2003;14:1188-1199.

7 Kale S, Karihaloo A, Clark PR, Kashgarian M, Krause DS, Cantley LG: Bone marrow stem cells contribute to repair of the ischemically injured renal tubule. J Clin Invest 2003; 112:42-49.

$\checkmark 8$ Szczypka MS, Westover AJ, Clouthier SG, Ferrara JL, Humes HD: Rare incorporation of bone marrow-derived cells into kidney after folic acid-induced injury. Stem Cells 2005;23:44-54.

9 Duffield JS, Park KM, Hsiao LL, Kelley VR, Scadden DT, Ichimura T, Bonventre JV: Restoration of tubular epithelial cells during repair of the postischemic kidney occurs independently of bone marrow-derived stem cells. J Clin Invest 2005; 115:1743-1755.
10 Krause D, Cantley LG: Bone marrow plasticity revisited: protection or differentiation in the kidney tubule? J Clin Invest 2005;115: 1705-1708.

11 Lin F, Moran A, Igarashi P: Intrarenal cells, not bone marrow-derived cells, are the major source for regeneration in postischemic kidney. J Clin Invest 2005;115:1756-1764.

12 Witzgall R, Brown D, Schwartz C, Bonventre J: Localization of proliferating cell nuclear antigen, vimentin, $\mathrm{c}$-fos, and clusterin in the postischemic kidney. Evidence for a heterogenous genetic response among nephron segments, and a large pool of mitotically active and dedifferentiated cells. J Clin Invest 1994; 93:2175-2188.

13 Safirstein R, Price PM, Saggi SJ, Harris RC: Changes in gene expression after temporary renal ischemia. Kidney Int 1990;37:15151521. 
14 Safirstein R: Gene expression in nephrotoxic and ischemic acute renal failure. J Am Soc Nephrol 1994;4:1387-1395.

15 Bacallao R, Fine LG: Molecular events in the organization of renal tubular epithelium: from nephrogenesis to regeneration. Am J Physiol 1989;257(6 Pt 2):F913-F924.

-16 Safirstein R: Renal regeneration: reiterating a developmental paradigm. Kidney Int 1999; 56:1599.

$\checkmark 17$ Maeshima A, Maeshima K, Nojima Y, Kojima I: Involvement of Pax-2 in the action of activin A on tubular cell regeneration. J Am Soc Nephrol 2002;13:2850-2859.

-18 Imgrund M, Gröne E, Gröne HJ, Kretzler M, Holzman L, Schlöndorff D, Rothenpieler UW: Re-expression of the developmental gene Pax-2 during experimental acute tubular necrosis in mice. Kidney Int 1999;56: 1423-1431.

-19 Devarajan P, Mishra J, Supavekin S, Patterson LT, Steven Potter S: Gene expression in early ischemic renal injury: clues towards pathogenesis, biomarker discovery, and novel therapeutics. Mol Genet Metab 2003;80: 365-376.

-20 Alison MR, Poulsom R, Forbes S, Wright NA: An introduction to stem cells. J Pathol 2002;197:419-423.

-21 Lin F, Moran A, Igarashi P: Intrarenal cells, not bone marrow-derived cells, are the major source for regeneration in postischemic kidney. J Clin Invest 2005;115:1756-1764.

-22 Bonventre J: Dedifferentiation and proliferation of surviving epithelial cells in acute renal failure. J Am Soc Nephrol 2003;14(Suppl 1):S55-S61.

23 Lameire N, Van Biesen W, Vanholder R Acute renal failure. Lancet 2005;365:417430.

-24 Chertow GM, Levy EM, Hammermeister KE, Grover F, Daley J: Independent association between acute renal failure and mortality following cardiac surgery. Am J Med 1998;104:343-348.

25 Basile DP, Fredrich K, Alausa M, Vio CP, Li ang M, Rieder MR, Greene AS, Cowley AW Jr: Identification of persistently altered gene expression in the kidney after functional recovery from ischemic acute renal failure. Am J Physiol Renal Physiol 2005;288:F953F963.

-26 Herzlinger D, Koseki C, Mikawa T, Al-Awqati Q: Metanephric mesenchyme contains multipotent stem cells whose fate is restricted after induction. Development 1992;114: 565-572.

-27 Oliver JA, Barasch J, Yang J, Herzlinger D, Al-Awqati Q: Metanephric mesenchyme contains embryonic renal stem cells. Am J Physiol Renal Physiol 2002;283:F799-F809.

-28 Singh SR, Liu W, Hou SX: The adult Drosophila Malpighian tubules are maintained by multipotent stem cells. Cell Stem Cell 2007;1:191-203.
29 Drummond IA, Mukhopadhyay D, Sukhatme VP: Expression of fetal kidney growth factors in a kidney tumor line: role of FGF2 in kidney development. Exp Nephrol 1998;6: 522-533.

30 Elger M, Hentschel H, Litteral J, Wellner M, Kirsch T, Luft FC, Haller H: Nephrogenesis is induced by partial nephrectomy in the elasmobranch Leucoraja erinacea. J Am Soc Nephrol 2003;14:1506-1518.

31 Salice CJ, Rokous JS, Kane AS, Reimschues sel R: New nephron development in goldfish (Carassius auratus) kidneys following repeated gentamicin-induced nephrotoxicosis. Comp Med 2001;51:56-59.

32 Challen GA, Martinez G, Davis MJ, Taylor DF, Crowe M, Teasdale RD, Grimmond SM, Little MH: Identifying the molecular phenotype of renal progenitor cells. J Am Soc Nephrol 2004;15:2344-2357.

33 Hammerman MR: Organogenesis of kidneys following transplantation of renal progenitor cells. Transpl Immunol 2004;12: 229-239.

34 Dekel B, Burakova T, Arditti FD, Reich-Zeliger S, Milstein O, Aviel-Ronen S, Rechavi G, Friedman N, Kaminski N, Passwell JH, Reisner Y: Human and porcine early kidney precursors as a new source for transplantation. Nat Med 2003;9:53-60.

35 Challen GA, Little MH: A side order of stem cells: the SP phenotype. Stem Cells 2006;24: 3-12.

36 Oliver JA, Maarouf O, Cheema FH, Martens $\mathrm{TP}, \mathrm{Al}$-Awqati Q: The renal papilla is a niche for adult kidney stem cells. J Clin Invest 2004;114:795-804.

37 Maeshima A, Yamashita S, Nojima Y: Identification of renal progenitor-like tubular cells that participate in the regeneration processes of the kidney. J Am Soc Nephrol 2003;14: 3138-3146.

38 Maeshima A, Sakurai H, Nigam SK: Adult kidney tubular cell population showing phenotypic plasticity, tubulogenic capacity, and integration capability into developing kidney. J Am Soc Nephrol 2006;17:188-198.

39 Iwatani $\mathrm{H}$, Ito T, Imai E, Matsuzaki Y, Suzuki A, Yamato M, Okabe M, Hori M: Hematopoietic and nonhematopoietic potentials of Hoechst(low)/side population cells isolated from adult rat kidney. Kidney Int 2004;65: 1604-1614.

40 Hishikawa K, Marumo T, Miura S, Nakanishi A, Matsuzaki Y, Shibata K, Ichiyanagi T, Kohike H, Komori T, Takahashi I, Takase O, Imai $\mathrm{N}$, Yoshikawa $\mathrm{M}$, Inowa $\mathrm{T}$, Hayashi $\mathrm{M}$, Nakaki T, Nakauchi H, Okano H, Fujita T: Musculin/MyoR is expressed in kidney side population cells and can regulate their function. J Cell Biol 2005; 169:921-928.

41 Challen GA, Bertoncello I, Deane JA, Ricardo SD, Little MH: Kidney side population reveals multilineage potential and renal functional capacity but also cellular heterogeneity. J Am Soc Nephrol 2006;17:1896-1912.
42 Bussolati B, Bruno S, Grange C, Buttiglieri S, Deregibus MC, Cantino D, Camussi G: Isolation of renal progenitor cells from adult human kidney. Am J Pathol 2005; 166:545555.

43 Sagrinati C, Netti GS, Mazzinghi B, Lazzeri E, Liotta F, Frosali F, Ronconi E, Meini C, Gacci M, Squecco R, Carini M, Gesualdo L, Francini F, Maggi E, Annunziato F, Lasagni L, Serio M, Romagnani S, Romagnani P: Isolation and characterization of multipotent progenitor cells from the Bowman's capsule of adult human kidneys. J Am Soc Nephrol 2006; 17:2443-2456.

44 Dekel B, Zangi L, Shezen E, Reich-Zeliger S, Eventov-Friedman S, Katchman H, JacobHirsch J, Amariglio N, Rechavi G, Margalit $\mathrm{R}$, Reisner $\mathrm{Y}$ : Isolation and characterization of nontubular sca-1+lin- multipotent stem/ progenitor cells from adult mouse kidney. J Am Soc Nephrol 2006;17:3300-3314.

45 Kitamura S, Yamasaki Y, Kinomura M, Sugaya $T$, Sugiyama $H$, Maeshima $Y$, Makino $\mathrm{H}$ : Establishment and characterization of renal progenitor-like cells from S3 segment of nephron in rat adult kidney. FASEB J 2005; 19:1789-1797.

46 Gupta S, Verfaillie C, Chmielewski D, Kren S, Eidman K, Connaire J, Heremans Y, Lund T, Blackstad M, Jiang Y, Luttun A, Rosenberg ME: Isolation and characterization of kidney-derived stem cells. J Am Soc Nephrol 2006;17:3028-3040.

47 Dyce PW, Zhu H, Craig J, Li J: Stem cells with multilineage potential derived from porcine skin. Biochem Biophys Res Commun 2004; 316:651-658.

48 Yeom YI, Fuhrmann G, Ovitt CE, Brehm A, Ohbo K, Gross M, Hübner K, Schöler HR: Germline regulatory element of Oct-4 specific for the totipotent cycle of embryonal cells. Development 1996;122:881-894.

49 Mitalipov SM, Kuo HC, Hennebold JD, Wolf DP: Oct-4 expression in pluripotent cells of the rhesus monkey. Biol Reprod 2003;69: 1785-1792.

50 Kehler J, Tolkunova E, Koschorz B, Pesce M, Gentile L, Boiani M, Lomelí H, Nagy A, McLaughlin KJ, Schöler HR, Tomilin A: Oct4 is required for primordial germ cell survival. EMBO Rep 2004;5:1078-1083.

51 Pesce M, Schöler HR: Oct-4: control of totipotency and germline determination. Mol Reprod Dev 2000;55:452-457.

52 Rosner MH, Vigano MA, Ozato K, Timmons PM, Poirier F, Rigby PW, Staudt LM: A POUdomain transcription factor in early stem cells and germ cells of the mammalian embryo. Nature 1990;345:686-692.

53 Reubinoff BE, Pera MF, Fong CY, Trounson A, Bongso A: Embryonic stem cell lines from human blastocysts: somatic differentiation in vitro. Nat Biotechnol 2000;18:399-404. 
54 Niwa H, Miyazaki J, Smith AG: Quantitative expression of Oct-3/4 defines differentiation, dedifferentiation or self-renewal of ES cells. Nat Genet 2000;24:372-376.

-55 Jiang Y, Vaessen B, Lenvik T, Blackstad M, Reyes M, Verfaillie C: Multipotent progenitor cells can be isolated from postnatal murine bone marrow, muscle, and brain. Exp Hematol 2002;30:896-904.

-56 Jiang Y, Jahagirdar BN, Reinhardt RL, Schwartz RE, Keene CD, Ortiz-Gonzalez XR, Reyes M, Lenvik T, Lund T, Blackstad M, Du J, Aldrich S, Lisberg A, Low WC, Largaespada DA, Verfaillie C: Pluripotency of mesenchymal stem cells derived from adult marrow. Nature 2002;418:41-49.

57 Schwartz RE, Reyes M, Koodie L, Jiang Y, Blackstad M, Lund T, Lenvik T, Johnson S, Hu WS, Verfaillie C: Multipotent adult progenitor cells from bone marrow differentiate into functional hepatocyte-like cells. J Clin Invest 2002;109:1291-1302.

58 Reyes M, Dudek A, Jahagirdar BN, Koodie L, Marker PH, Verfaillie C: Origin of endothelial progenitors in human postnatal bone marrow. J Clin Invest 2002;109:337-346.

-59 Yu H, Fang D, Kumar SM, Li L, Nguyen TK, Acs G, Herlyn M, Xu X: Isolation of a novel population of multipotent adult stem cells from human hair follicles. Am J Pathol 2006; 168:1879-1888.

60 Baal N, Reisinger K, Jahr H, Bohle RM, Liang O, Münstedt K, Rao CV, Preissner KT, Zygmunt MT: Expression of transcription factor Oct-4 and other embryonic genes in CD133 positive cells from human umbilical cord blood. Thromb Haemost 2004;92:767-775.

-61 D'Ippolito G, Diabira S, Howard GA, Menei P, Roos BA, Schiller PC: Marrow-isolated adult multilineage inducible (MIAMI) cells, a unique population of postnatal young and old human cells with extensive expansion and differentiation potential. J Cell Sci 2004; 117(Pt 14):2971-2981.
62 Davis SF, Hood J, Thomas A, Bunnell BA: Isolation of adult rhesus neural stem and progenitor cells and differentiation into immature oligodendrocytes. Stem Cells Dev 2006;15:191-199.

63 Romagnani P, Annunziato F, Liotta F, Lazzeri E, Mazzinghi B, Frosali F, Cosmi L, Maggi L, Lasagni L, Scheffold A, Kruger M, Dimmeler S, Marra F, Gensini G, Maggi E, Romagnani S: CD14+CD34low cells with stem cell phenotypic and functional features are the major source of circulating endothelial progenitors. Circ Res 2005;97:314-322.

64 Romero-Ramos M, Vourc'h P, Young HE, Lucas PA, Wu Y, Chivatakarn O, Zaman R, Dunkelman N, el-Kalay MA, Chesselet MF: Neuronal differentiation of stem cells isolated from adult muscle. J Neurosci Res 2002; 69:894-907.

65 Trosko JE, Tai MH: Adult stem cell theory of the multi-stage, multi-mechanism theory of carcinogenesis: role of inflammation on the promotion of initiated stem cells. Contrib Microbiol 2006;13:45-65.

66 Tsai MS, Hwang SM, Tsai YL, Cheng FC, Lee JL, Chang YJ: Clonal amniotic fluid-derived stem cells express characteristics of both mesenchymal and neural stem cells. Biol Reprod 2006;74:545-551.

67 Xiao J, Nan Z, Motooka Y, Low WC: Transplantation of a novel cell line population of umbilical cord blood stem cells ameliorates neurological deficits associated with ischemic brain injury. Stem Cells Dev 2005;14: 722-733.

68 Zhou YF, Fang F, Fu JR, Dong YS, Ye DY, Shu SN, Zhen H, Li G: An experimental study on astrocytes promoting production of neural stem cells derived from mouse embryonic stem cells. Chin Med J (Engl) 2005;118: 1994-1999.

69 Iwano M, Plieth D, Danoff TM, Xue C, Okada H, Neilson EG: Evidence that fibroblasts derive from epithelium during tissue fibrosis. J Clin Invest 2002;110:341-350.
70 Zeisberg M, Hanai J, Sugimoto H, Mammoto T, Charytan D, Strutz F, Kalluri R: BMP-7 counteracts TGF-betal-induced epithelialto-mesenchymal transition and reverses chronic renal injury. Nat Med 2003;9:964968.

71 Zeisberg M, Kalluri R: The role of epithelialto-mesenchymal transition in renal fibrosis. J Mol Med 2004;82:175-181.

72 Zeisberg M, Shah AA, Kalluri R: Bone morphogenic protein-7 induces mesenchymal to epithelial transition in adult renal fibroblasts and facilitates regeneration of injured kidney. J Biol Chem 2005;280:8094-8100.

73 Zager RA, Johnson AC, Lund S, Hanson SY: Acute renal failure: determinants and characteristics of the injury-induced hyperinflammatory response. Am J Physiol Renal Physiol 2006;291:F546-F556.

74 Zager RA, Johnson AC, Hanson SY, Lund S: Acute nephrotoxic and obstructive injury primes the kidney to endotoxin-driven cytokine/chemokine production. Kidney Int 2006;69:1181-1188.

75 Nath KA, Norby SM: Reactive oxygen species and acute renal failure. Am J Med 2000; 109:665-678.

76 Nath KA: Heme oxygenase-1: a provenance for cytoprotective pathways in the kidney and other tissues. Kidney Int 2006;70:432443.

77 Nath KA: Adaptation to the nephrotoxicity of heme proteins. Exp Nephrol 1996;4:139143.

78 Hammerman MR, Miller SB: Therapeutic use of growth factors in renal failure. J Am Soc Nephrol 1994;5:1-11.

79 Hirschberg R, Kopple J, Lipsett P, et al: Multicenter trial of recombinant human insulinlike growth factor I in patients with acute renal failure. Kidney Int 1999;55:2423-2432. 